\title{
Anisotropic Components
}

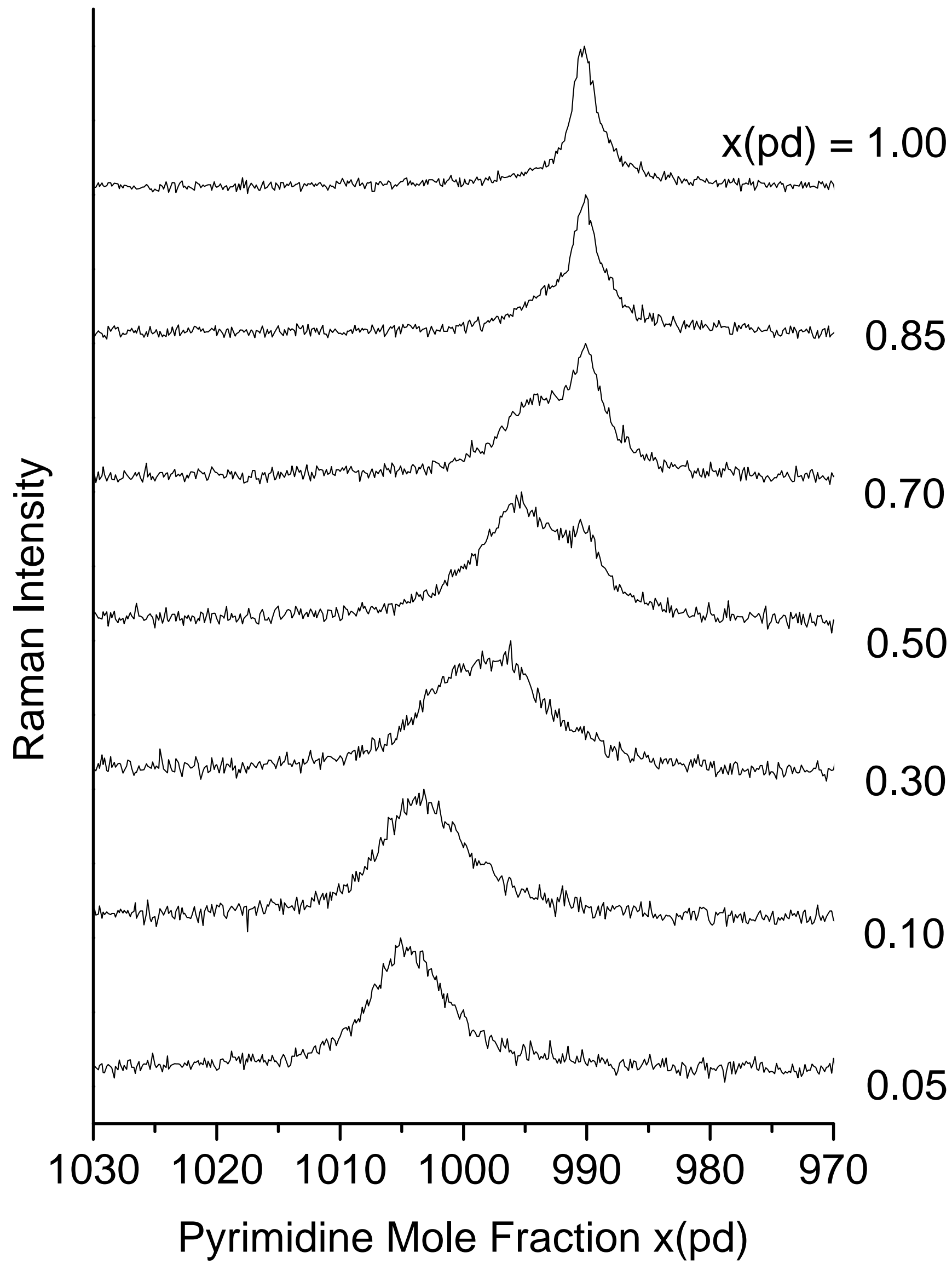

